\title{
CENTRO DE MATERIAL E ESTERILIZAÇÃO E O PAPEL FUNDAMENTAL E AMPLO NA QUALIDADE DA ATENÇÃO
}

DOI: 10.5327/Z1414-4425201700020001

A atenção de saúde com qualidade e segurança, entre outras características, é a missão de todos os serviços de saúde. E evitar que as infecções associadas à atenção de saúde ocorram é parte importante dessa missão. A Central de Material e Esterilização (CME), que se dedica exclusivamente a evitar que ocorra a transmissão de infecção dentro dos serviços de saúde, faz isto por meio do processo de esterilização.

Quando a centralização do processo de esterilização foi proposta nos anos 1950-1960, o objetivo era garantir a qualidade dos processos que aí se realizavam e torná-los mais baratos. Naquela época, a CME se dedicava a garantir a qualidade dos procedimentos cirúrgicos e a prevenção de infecções de sítio cirúrgico era o seu principal objetivo. Com o desenvolvimento da tecnologia médica e o aumento da complexidade da atenção prestada nos serviços de saúde, o uso de equipamentos limpos e desinfetados ou esterilizados passou a ser uma necessidade. Os equipamentos invasivos se multiplicaram e passaram a ser utilizados em várias outras áreas do hospital, cabendo à CME apoiar a prevenção de infecções, tais como pneumonia ou infecção urinária.

Ao aumentar sua abrangência, cresceu também a importância da CME na garantia da qualidade do cuidado prestado ao paciente/ cliente, muito além do eixo central de esterilização e centro cirúrgico. O impacto do que ocorre na CME é visível e tem garantido cirurgias e cuidados seguros a muitas pessoas. A falta dessas boas práticas tem sido relacionada a surtos de infecções e danos aos pacientes. E somente a implementação delas, baseadas em evidências, pode evitar que essas situações ocorram, garantindo a qualidade e a segurança da assistência prestada.

O uso de material esterilizado para prevenção das infecções de sítio cirúrgico é a primeira recomendação e, possivelmente, a de maior impacto na prevenção dessas infecções. A limpeza e a esterilização de material cirúrgico são boas práticas inquestionáveis e fundamentais. Tão essenciais que, por questões éticas, paradoxalmente, seu impacto só pode ser medido pela falta ou quebra desse processo quando ocorrem surtos e infecções de sítio cirúrgico, e não pela presença dessas ações quando o desfecho é favorável para o paciente.

Usar equipamentos ou instrumentos esterilizados ou desinfetados é sugerido em todos os manuais e publicações das instituições internacionais e nacionais para a prevenção de infecções que são transmitidas em serviços de saúde. Um bom exemplo é a desinfecção de artigos respiratórios, traqueais, tubos e equipamentos de assistência ventilatória, fundamental para a prevenção de pneumonia. Outro exemplo é a utilização de cálices limpos e desinfetados, o que evita a colonização da bolsa coletora e reduz as chances de uma infecção urinária.

A quebra de técnica no processo de esterilização ou desinfecção foi descrita como causa de vários surtos de infecção de sítio cirúrgico ou de infecções ocorridas depois de procedimentos endoscópicos. Todas essas infecções poderiam ter sido evitadas e, por não terem sido, acarretaram um alto custo para os pacientes e o sistema de saúde.

Alcançar o objetivo de prestação de serviços de saúde com segurança e qualidade depende da aplicação de processos e procedimentos seguros e baseados em evidência científica. A aplicação desses dois fatores exige dos profissionais a leitura crítica e atenta de artigos científicos atuais e selecionados pela excelência. A Associação Brasileira de Enfermeiros de Centro Cirúrgico, Recuperação Anestésica e Centro de Material e Esterilização (SOBECC) auxilia os profissionais por esse caminho de conhecimento, melhorando a qualidade e a segurança do trabalho que se realiza na CME por meio das informações e dos artigos publicados.

Valeska Stempliuk Assessora Regional em Controle de Infeç̧ões da Organização Pan-Americana da Saúde/Organização Mundial da SaúdeWashington, D.C., EUA. 